\title{
Effects of Solvent/Solid Ratio and Temperature on the Kinetics of Vitamin C Extraction from Musa Acuminata
}

\author{
Khairul Anwar Mohamad Said ${ }^{1}$, Ibrahim Yakub ${ }^{2}$ and Nurul Ain Mohamed Alipah ${ }^{3}$ \\ ${ }^{1,2,3}$ Department of Chemical Engineering, Universiti Malaysia Sarawak, \\ Kota Samarahan, Malaysia. \\ ${ }^{1}$ Email:mskanwar@feng.unimas.my \\ 2yibrahim@feng.unimas.my \\ ${ }^{3}$ Email: 3mhdplh@yahoo.com
}

\begin{abstract}
This work studied on the kinetics of Vitamin C extraction from banana peel at different solvent/solid concentration and temperature. Musa Acuminata was ground into smaller sizes before contacted with methanol as a solvent in an ultrasonic bath. To study the effect of solvent/solid ratio, 4.5, 5.0 and 10.0 $\mathrm{ml} / \mathrm{g}$ ratio were used for the extraction at fixed temperature. Then, the temperature was varied with the heating element available in the ultrasonic bath at 30,45 and $60{ }^{\circ} \mathrm{C}$, to study the effect of temperature on the extraction kinetics. It was found that high solvent/solid ratio $(10 \mathrm{ml} / \mathrm{g})$ provides more solutesolvent contact and prevents the extracted Vitamin $C$ from coming into contact with the air. Besides, higher temperature $\left(60^{\circ} \mathrm{C}\right)$ contributes sufficient kinetic energy for Vitamin $C$ distribution in the solvent which is important to prevent degradation with air. The best fitted kinetic model for Vitamin C extraction from Musa Acuminata is Ana et al. (2007) with equilibrium concentration of $0.05 \mathrm{~g} / \mathrm{L}$ and $0.40 \mathrm{~g} / \mathrm{L} . \mathrm{hr}$ extraction rate
\end{abstract}

Keywords: kinetic model, vitamin C, solid/solvent ratio, temperature

\section{Introduction}

Bananas and plantains are great source of calories, carbohydrate, potassium, starch, provitamin A and other carotenoids. Due to their contents of phytochemicals compounds, bananas exhibit biological properties such as antioxidants, antimicrobial, anti-ulcerogenic, anti-inflammatory, anti-proliferative and anticancer activities [1]. More importantly, banana is an antioxidant-rich fruit because in common, a bright colored fruits indicate the presence of antioxidants.

Antioxidants are chemicals that resist or neutralize oxidation in cells. Every dietary source of antioxidants comes from secondary plant metabolites. It scavenge free radicals by inhibiting reaction within cells brought about by dioxygen or peroxide molecules, also called reactive nitrogen species. Flavonoids or bioflavonoids are secondary plant metabolites and the majority of its function was antioxidants which commonly found in food and beverages [2].

In general, ascorbic acid or Vitamin $\mathrm{C}$ is a natural antioxidant that primarily exists in fruits and vegetables which is available in its reduced form as $\mathrm{L}$-ascorbic acid and its oxidized form as $\mathrm{L}$ dehydroascorbic acid [3]. Vitamin $\mathrm{C}$ or ascorbic acid is an antioxidant that is soluble in water, unstable, easily oxidized acid and can be deteriorated by oxygen, alkali and high temperature.

For the last few years, the consumer demand of nature-derived products gave a rising impact on various areas like food industry, nutraceuticals, cosmetics, flavors/fragrances, and also the pharmaceutical industry [4]. Many new extraction technologies like ultrasonic-assisted extraction,

Manuscript History:

Received 12 August, 2015, Revised 17 September, 2015, Accepted 21 September, 2015, Published 30 September, 2015

e-ISSN 2289-7771

Copyright $(9) 2015$ JASPE

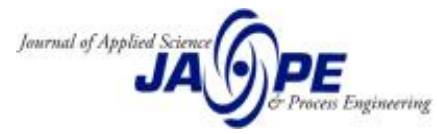

